\title{
ACTIVITIES ASSESSMENT AS A TOOL TO MEASURE STUDENTS' OBSERVATION SKILLS IN SCIENCE LEARNING
}

\section{${ }^{1}$ Binar Ayu Dewanti}

Department of Science Education, Faculty of Teacher Training and Education, Lamongan Islamic University. Jl. Veteran No.53A Lamongan, Indonesia .

Email: binarayudewanti@unisla.ac.id binarayu91@gmail.com

\section{Article History}

Received: 11 January

Revised: 26 February

Published: March 2019

\begin{abstract}
(10pt italic)
Observation skills are one of the basic skills students must possess in science learning. Through observation skills, students are able to identify facts or initial knowledge before going on to the next stage of the science process skills. In science learning, student observation skills can be observed and measured through all learning activities both in the classroom and in the laboratory (practicum) by using the activity assessment sheet. Activity assessment sheet is a derivative form of performance assessment consisting of 1) student identity, 2) assessment instructions, 3) basic competencies, 4) assessment table (sub-material, observed observation skills, scores, and information), 5) formulation acquisition of final score, and 6) assessment rubric. The assessment sheet for this activity has been tested on 44 junior high school students and the average results reached more than $50 \%$ of students showing the highest score of observation skills. Thus, the activity assessment sheet can be said to be used to measure student observation skills.
\end{abstract}

Keywords: assessment, activity, observation

\author{
How to cite: Ayu Dewanti, Binar. (2019). ACTIVITIES ASSESSMENT AS A TOOL TO MEASURE \\ STUDENTS' OBSERVATION SKILLS IN SCIENCE LEARNING. Science Education and Application \\ Journal (SEAJ). Vol. 1 No.1: 17-24.
}

\section{INTRODUCTION}

Indonesia as one of the developing countries in the world often makes various kinds of changes and developments in all sectors of life. One of the concerns is the education sector. Education is a form of realization of the development of human culture that will occur continuously. Therefore, the innovation in the education sector is needed, of course, as a form of anticipation of the needs and challenges in the future.

Renewal in the field of education can be shown one of them through curriculum change. As has happened in recent years is the Curriculum of 2013. The Curriculum of 2013 is a form of educational innovation that is in line with the spirit of achieving the skills of students in the 21 st century (Zulkifli et al, 2019). With the Curriculum of 2013, Indonesia is expected to be able to prepare human resources who have superior competence, high competitiveness, and are able to contribute to the life of the community, nation, and state.

Changes in curriculum systems cause changes in the complementary components of learning, one of which is the assessment system. Research is one of the important components in a curriculum. As revealed by $\mathrm{Li}$ et al (2018), "To be educated as scientifically literate persons, students need to be appropriately assessed." To know someone educated or achieve the expected learning competencies, it is needed a scoring system. Assessment can also be said as the final activity of a series of learning activities to provide an overview of the quality of these learning activities. In the Curriculum of 2013, there was reinforcement in the learning and assessment process, one of which was the use of scientific approaches (observing, asking, reasoning, trying, networking (collaborative)) and measuring student work processes, not 
student work (Kemdikbud, 2013). This strengthening is expected to be applied in all fields of study which are study material in the curriculum, which one of them is science.

Science was born and developed through systematic scientific procedures, namely observation, problem formulation, preparation and testing of hypotheses, experimentation, up to drawing conclusions until the students find theories and concepts (Ariyawati et al, 2017). Science learning also said as learning that pays attention to three important scientific aspects, namely processes, products, and attitudes (Sugiarti, et al 2017). This shows that science learning is not only related to the mastery of concepts and theories, but also through the process of finding out the concept of knowledge itself through a series of scientific procedures. The activity of observation is one of the activities included in the scientific process.

Observation activities are part of the science process skills. Process skills are an approach in science learning based on observational activities carried out by a scientist (Subiyanto, in Hilmi et al (2018)). The importance of observation skills as part of the science process skills in learning are strengthened by Aktamiş statement ( in Aktamiş \& Yenice (2010) ), according to him "... all people in society should have these skills in order to be scientifically literate and solve problems encountered in daily life ." Based on the statement above, observation skills as part of the science process skills are the basic skills that students must have in science learning. There are several indicators that indicate that a student performs observational activities, including: 1) using all the senses in their interactions, 2) organizing objects based on certain traits, 3) identifying many traits, 4) making quantitative observations, and 5) making qualitative observations (Trianto, 2010).

Referring to the demands and urgency of the scoring system in the Curriculum of 2013 in science learning, the relevant forms of assessment used are authentic assessments. Through authentic assessment, skills and performance can be measured, not only in remembering facts (Kunandar, 2014). That is, authentic assessment is able to measure everything that is as it is and contextually in accordance with all forms of activities carried out by students in learning activities. Therefore, authentic forms of assessment are very diverse. One of them is performance assessment (performance). Performance evaluation is a form of assessment that is able to show the students' knowledge and skills through the carried out activities (Marmara, in Diartha \& Muntari (2013)). Activity assessment sheet is one other form of instrument performance appraisal or performance. The activity assessment sheet is an instrument used to assess all forms of activities or activities carried out by students during the learning process.

Indonesia as one of the developing countries in the world often makes various kinds of changes and developments in all sectors of life. One of the concerns is the education sector. Education is a form of realization of the development of human culture that will occur continuously. Therefore, the innovation in the education sector is needed, of course, as a form of anticipation of the needs and challenges in the future.

Renewal in the field of education can be shown one of them through curriculum change. As has happened in recent years is the Curriculum of 2013. The Curriculum of 2013 is a form of educational innovation that is in line with the spirit of achieving the skills of students in the 21st century (Zulkifli et al, 2019). With the Curriculum of 2013, Indonesia is expected to be able to prepare human resources who have superior competence, high competitiveness, and are able to contribute to the life of the community, nation, and state.

Changes in curriculum systems cause changes in the complementary components of learning, one of which is the assessment system. Research is one of the important components in a curriculum. As revealed by $\mathrm{Li}$ et al (2018), "To be educated as scientifically literate persons, students need to be appropriately assessed." To know someone educated or achieve the expected learning competencies, it is needed a scoring system. Assessment can also be said as the final activity of a series of learning activities to provide an overview of the quality of these learning activities. In the Curriculum of 2013, there was reinforcement in the learning and assessment process, one of which was the use of scientific approaches (observing, asking, 
reasoning, trying, networking (collaborative)) and measuring student work processes, not student work (Kemdikbud, 2013). This strengthening is expected to be applied in all fields of study which are study material in the curriculum, which one of them is science.

Science was born and developed through systematic scientific procedures, namely observation, problem formulation, preparation and testing of hypotheses, experimentation, up to drawing conclusions until the students find theories and concepts (Ariyawati et al, 2017). Science learning also said as learning that pays attention to three important scientific aspects, namely processes, products, and attitudes (Sugiarti, et al 2017). This shows that science learning is not only related to the mastery of concepts and theories, but also through the process of finding out the concept of knowledge itself through a series of scientific procedures. The activity of observation is one of the activities included in the scientific process.

Observation activities are part of the science process skills. Process skills are an approach in science learning based on observational activities carried out by a scientist (Subiyanto, in Hilmi et al (2018)). The importance of observation skills as part of the science process skills in learning are strengthened by Aktamiş statement ( in Aktamiş \& Yenice (2010) ), according to him "... all people in society should have these skills in order to be scientifically literate and solve problems encountered in daily life ." Based on the statement above, observation skills as part of the science process skills are the basic skills that students must have in science learning. There are several indicators that indicate that a student performs observational activities, including: 1) using all the senses in their interactions, 2) organizing objects based on certain traits, 3) identifying many traits, 4) making quantitative observations, and 5) making qualitative observations (Trianto, 2010).

Referring to the demands and urgency of the scoring system in the Curriculum of 2013 in science learning, the relevant forms of assessment used are authentic assessments. Through authentic assessment, skills and performance can be measured, not only in remembering facts (Kunandar, 2014). That is, authentic assessment is able to measure everything that is as it is and contextually in accordance with all forms of activities carried out by students in learning activities. Therefore, authentic forms of assessment are very diverse. One of them is performance assessment (performance). Performance evaluation is a form of assessment that is able to show the students' knowledge and skills through the carried out activities (Marmara, in Diartha \& Muntari (2013). Activity assessment sheet is one other form of instrument performance appraisal or performance. The activity assessment sheet is an instrument used to assess all forms of activities or activities carried out by students during the learning process.

The activity assessment sheet as one form of authentic assessment is an assessment technique that is still rarely performed in science learning activities in the Curriculum of 2013. This is based on the results of interviews with several science teachers in junior high schools who have applied Curriculum of 2013, most forms of assessment used in science learning is an assessment of student learning outcomes tests. Skill form assessment students are occasionally done if the learning activities are accompanied by practicum activities, but even so, the instrument is not accompanied by clear and operational assessment instructions so that sometimes there are still some student activities that are not measurable in the assessment instrument.

Observation activities are activities that always involve physical activity (motoric) so that each form of student behavior in learning activities can be observed. Therefore, the activity assessment sheet can be used as a tool to measure student observation skills. With the activity assessment sheet, all developments in student observation skills can be illustrated. The student activity assessment sheet is structured in such a way as to match the indicators of the competencies that want to measure. Therefore, the activity assessment sheet can be used both in classroom learning activities and in the laboratory.

The activity assessment sheet cannot function optimally without the rubric. A rubric is a reference and criteria in giving a score to the abilities shown by students (Sudria, 2009). In 
an assessment, the rubric is arranged in two forms, namely holistic rubric, and analytic rubric. In the activity assessment sheet, the rubric used is analytical rubric. The analytic rubric is that its use is very specific to a particular field of study or a material (Zainul, in Wulan, (2009). The analytic rubric is used to facilitate the assessment process, due to the concrete and operational description of each indicator, the provision of scoring in each indicator can be measured more accurately. This research is deemed important to do was based on the following considerations: 1) The need for science learning assessment instruments in accordance with the curriculum in 2013, and 2) the need for an assessment instrument to measure the activity of science process skills of students, one observation skills

\section{RESEARCH METHOD}

This research is a type of research and development ( R \& D) with a 4D development model. In general, the research was conducted in 4 stages, namely: 1) define, design, develop, and disseminate. The subjects of this study were 44 seventh grade students of the junior high school who were in the Curriculum of 2013 program in the even semester. The research variable is the independent variable namely the activity assessment instrument and the dependent variable is student observation skills.

Before being tested in the field, the activity assessment sheet has gone through the stages of defining, designing, and initial development stages such as validation tests. From the test, this instrument has been said to be suitable for use in learning activities. In this article, research is focused on the results of product implementation in learning activities. The implementation of the activity assessment instrument was carried out in the science-practice activities in the laboratory. The activity assessment sheet is intended for science learning activities in the material "Temperature and Change".

Data obtained from research results are based on scores obtained by students on each indicator. There are several indicators that show observation skills in the assessment. Scores obtained by students on each indicator will be collected and will be analyzed based on how many students get a certain score $(3,2$, or 1$)$ in percentage form. The conclusions are obtained from the results of the average percentage in each score.

\section{RESULTS AND DISCUSSION}

The purpose of this study is to produce a product of science learning evaluation that is in accordance with the Curriculum of 2013 approach, one of which is an assessment instrument to measure one of the students' science process skills, namely observing skills. In its implementation in the field, an activity assessment was used for 4 meetings in one trial on a discussion material.

\section{A. Product Characteristics}

The activity assessment sheet consists of several components, namely: 1) student identity, 2) assessment instructions, 3) learning competencies, 4) assessment tables, 5) final value formulation, and 6) assessment rubrics. The description for each component is as follows.

Table 1. Description of Components in the Student Activity Assessment Sheet

\begin{tabular}{lll}
\hline No. & \multicolumn{1}{c}{ Component } & \multicolumn{1}{c}{ Description } \\
\hline $1 . \quad$ Student Identity & $\begin{array}{l}\text { Contains information about the object of assessment. This section } \\
\text { consists of a) student name, b) class, c) absent number, } \mathrm{d}) \text { sub } \\
\text { material/subject matter, and } 5) \text { date of the activity. }\end{array}$ \\
& Contains instructions for using assessment instruments, such as how to \\
2. & Assessment Guide & score with a check mark $(\sqrt{ })$ and the meaning of the number of each \\
& &
\end{tabular}




\begin{tabular}{lll}
\hline No. & \multicolumn{1}{c}{ Component } & \multicolumn{1}{c}{ Description } \\
$3 . \quad$ Learning Competence & Contains core competencies and basic learning competencies. \\
$4 . \quad$ Assessment Table & $\begin{array}{l}\text { Consists of rows and columns containing sub-material, indicators of } \\
\text { observed observation skills, scores, and explanations. The assessment } \\
\text { table is a core part of the assessment instrument. All results of the } \\
\text { assessment are in this table. }\end{array}$ \\
$4 \quad \begin{array}{l}\text { Formulation of Obtaining Final } \\
\text { Score }\end{array}$ & $\begin{array}{l}\text { Contains a formula to obtain the final grade of student observation } \\
\text { skills. The mathematical formulations are: }\end{array}$ \\
& $\begin{array}{l}\text { Final Score }=\frac{\text { amount of score }}{12} \\
\text { Assessment Rubric }\end{array}$ & $\begin{array}{l}\text { Contains a description of the criteria for awarding scores } 1,2,3 \text { on } \\
\text { each assessment indicator (rubric analytic). }\end{array}$
\end{tabular}

The assessment table is a core part of the activity assessment sheet. One part of the assessment table is an indicator of observation skills. In each meeting, indicators of observation skills that measured are depend on the sub-material and expected competency. The description of indicators on aspects of the observation skills at each meeting along with the description of the rubric is as follows.

Table 2. Indicators of Student Observation Skills Assessment on Activity Activity Sheets

\begin{tabular}{|c|c|c|c|}
\hline $\begin{array}{c}\text { Basic } \\
\text { Competencies }\end{array}$ & Meeting & Sub Material & The indicator of Observation Skills \\
\hline
\end{tabular}

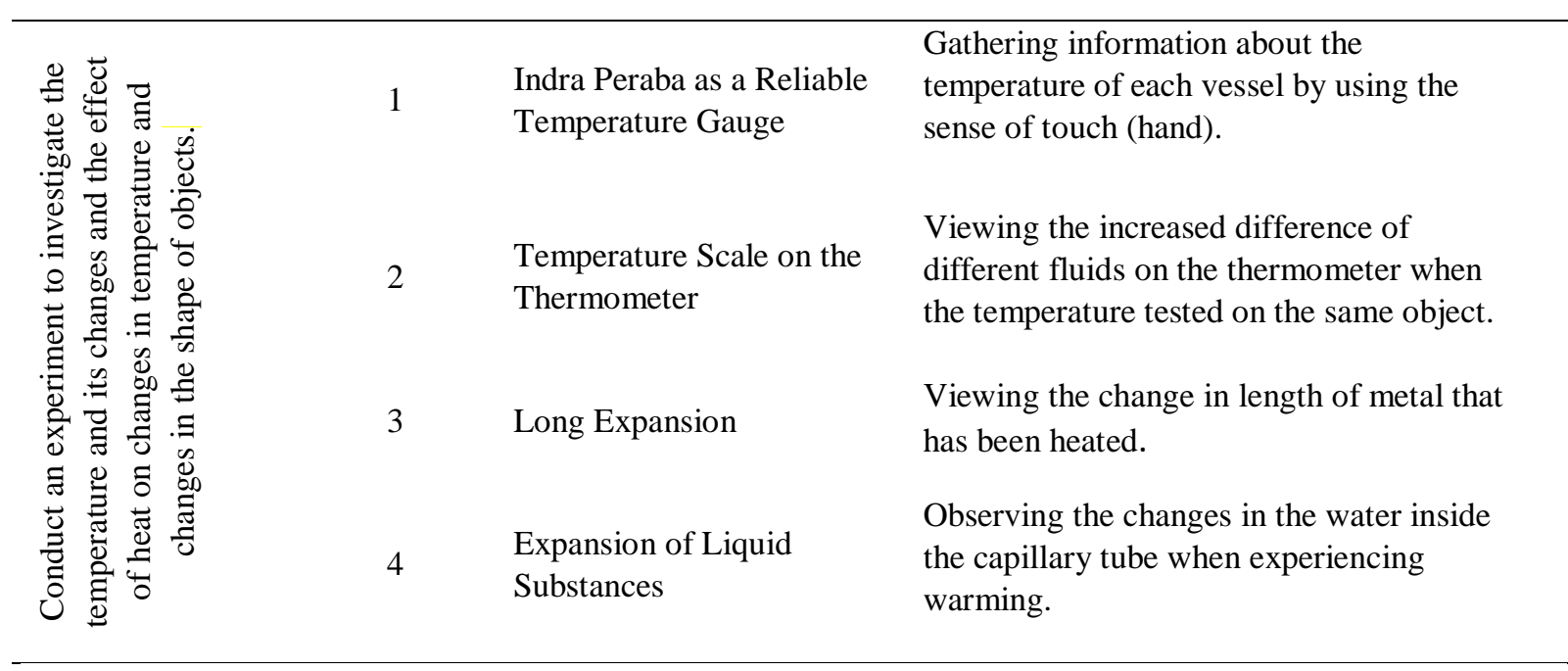

Table 3. Description of the Rubric Activity Assessment Sheet to Measure Observation Skills

\begin{tabular}{|c|c|c|c|}
\hline \multirow{2}{*}{ Assessment Criteria } & \multicolumn{3}{|c|}{ Score } \\
\hline & 3 & 2 & 1 \\
\hline $\begin{array}{l}\text { Gathering } \\
\text { information } \\
\text { about the } \\
\text { temperature of } \\
\text { each vessel by } \\
\text { using the sense } \\
\text { of touch (hand). }\end{array}$ & $\begin{array}{l}\text { Dipping hands directly } \\
\text { into all vessels. }\end{array}$ & $\begin{array}{l}\text { Dipping hands directly into } \\
\text { several vessels, the rest only } \\
\text { observes the responses shown by } \\
\text { other friends. }\end{array}$ & $\begin{array}{l}\text { Do not dip hands in } \\
\text { each vessel. }\end{array}$ \\
\hline
\end{tabular}




\begin{tabular}{|c|c|c|c|}
\hline \multirow{2}{*}{ Assessment Criteria } & \multicolumn{3}{|c|}{ Score } \\
\hline & 3 & 2 & 1 \\
\hline $\begin{array}{l}\text { Viewing the } \\
\text { increased difference } \\
\text { of different fluids } \\
\text { on the thermometer } \\
\text { when the } \\
\text { temperature tested } \\
\text { on the same object. }\end{array}$ & $\begin{array}{l}\text { See the difference in } \\
\text { the increase in the fluid } \\
\text { on a different } \\
\text { thermometer when } \\
\text { tested on objects with } \\
\text { the same temperature } \\
\text { carefully and carefully. }\end{array}$ & $\begin{array}{l}\text { Every now and then see the } \\
\text { difference in the increase in } \\
\text { the fluid on a different } \\
\text { thermometer when tested on } \\
\text { objects with the same } \\
\text { temperature. }\end{array}$ & $\begin{array}{l}\text { Do not see the } \\
\text { difference in the } \\
\text { increase in the fluid } \\
\text { on a different } \\
\text { thermometer when } \\
\text { tested on the same } \\
\text { temperature object. }\end{array}$ \\
\hline
\end{tabular}

Viewing the change in length of metal that has been heated.

Observing the changes in the water inside the capillary tube when experiencing warming.
See changes in metal length when the metal is carefully and carefully heated.

See changes that occur in water in the capillary tube when it is carefully and carefully heated.
Occasionally see changes in the length of the metal when the metal is heated.

\author{
Occasionally see changes that \\ occur in the water in the \\ capillary tube when \\ experiencing careful and \\ careful heating.
}

\author{
Do not see changes \\ in metal length \\ when the metal is \\ heated.
}
Do not see changes that occur in water in the capillary tube when it warms up.

In table 2, indicators of measured observation skills show students' initial skills when doing practical activities. For example, in the first meeting (the experiment activity "Sense of Touch as a Reliable Temperature Gauge"), based on the description of the indicators in table 2 , students are expected to be able to make temperature measurements using their hands. That is, to know whether or not the heat of an object is observed, students not only see symptoms visually but must touch the object directly. This is in accordance with one of the characteristics of the observation activity, namely finding out new knowledge through direct sensory activity. en

Student activity assessment sheet using scores 1 to 3 . If seen in table 2 , the description of each score shows a different level of skill competency. At score 1, the description shows the lowest level of activity. In score 2, the description shows a moderate level of activity. That is, students, do according to the skills or indicators described in the assessment, but not in full, or in other words still in the stage of developing skills. While in score 3, students are considered to have mastered the expected skills well. The value of student observation skills is obtained through summing the total scores obtained by each aspect then divided by the maximum score and multiplied by 100 .

Assessment rubrics are very important included in the activity assessment sheet to reduce any bias or judgment that is not objective and inauthentic. With the rubric, assessment activities not only carried out by the teacher, but also by observers or anyone who uses the instrument.

\section{B. Product Implementation}

The activity assessment sheet has been tested on 44 grade VII junior high school students. The results of the assessment instrument evaluation were analyzed by each indicator to find out how well the instrument was used to measure students' observation skills. The results of the analysis are presented in the following graph. 
$\square$ Score $3 \quad$ Score $2 \quad$ S Score 1

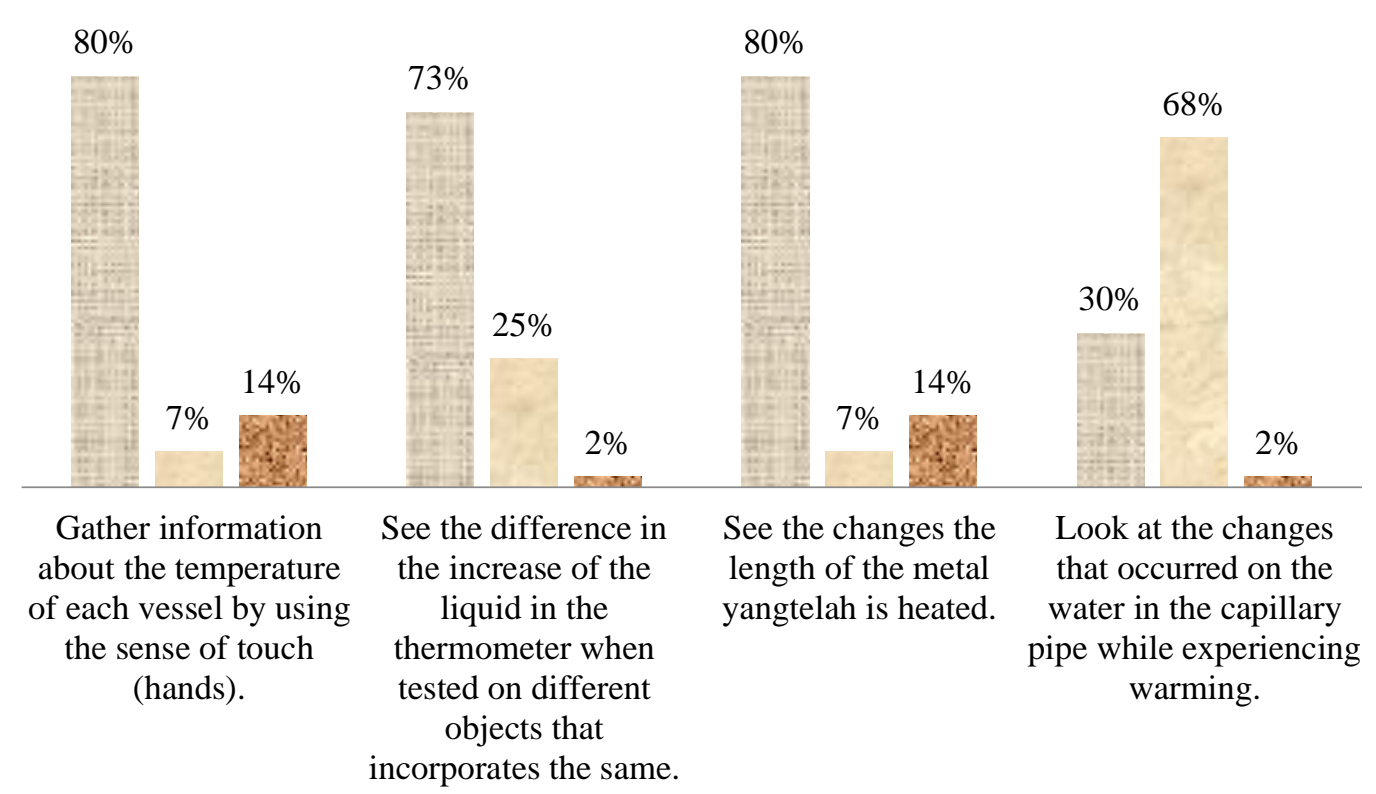

Figure 1. Graph of Percentage of Student Amounts in Obtaining Each Score in Each Indicator

On figure 1, the graph shows a significant difference in the value of the percentage of students who scored 3 with the number of students who scored 2 and 1 . Score 3 describes the score with the highest observation skills which are the score most obtained by students through student activity assessment instruments in almost all indicators of student observation skills. In the first and third indicators, there are $80 \%$ of students who get a score of 3 (good), on the second indicator students who get a score of 3 (good) is $73 \%$, and in the fourth indicator as many as $30 \%$ of students get a score of 3 (good). If average, the results obtained as much as $65 \%$ of students have observation skills in good categories, $27 \%$ of students have observation skills insufficient categories, and $8 \%$ of students have observation skills in fewer categories. It shows indicators in measuring the skills of observation on the assessment sheet activation can provide a clear picture of what observational skills competencies that must be achieved by the students.

This study aims to obtain an authentic science learning evaluation tool and in accordance with the Curriculum of 2013, especially to measure students' observation skills. Based on the description of the product characteristics described previously (in tables 1, 2, and 3 ), the activity assessment instrument is in accordance with the principles of authentic assessment, one of which is being able to measure students' competency skills, not just measuring knowledge competencies. Assessment sheets contain descriptions of activity indicator observational skills really adapted to the practical activities undertaken by students, so that all forms of student activities in the lab activities exposed to real or what it is. In addition, in the assessment instruments, the activity is also in accordance with one of the strengthening processes in the Curriculum of 2013, namely measuring the work process of students, not the work of students. In the activity assessment sheet, the measured competency is observation skills, where the skill is one part of the science process skills. The science process skills emphasize the science learning approach in finding facts, concepts, and theories of science (scientific products) through systematic scientific processes or methods.

The activity assessment sheet used to measure student observation skills is certainly inseparable from a number of shortcomings. Based on the opinion of the users of the instrument, namely the science study teacher, a cumulative activity assessment sheet should be attached to facilitate the assessment in the classroom, especially with a large number of 
students. This is intended so that assessment activities can be carried out more effectively and efficiently.

\section{CONCLUSION}

Observation skills are one of the skills of a scientific process that can be measured through direct observation. The skill of observation involves the whole use of the senses and becomes the starting point of students in constructing facts into concepts or knowledge that will develop through the stages of other skills. Based on the results of product implementation in the field, it can be said that the feasibility activity assessment sheet is used as a tool to measure student observation skills. This statement is based on several things, including: 1) the average number of students who get a score of 3 (good category) on all indicators of student observation skills reaching $65 \%$, or more than half the number of samples showing positive results, 2) instruments assessment of activities is in accordance with one of the principles of authentic assessment, namely being able to measure students' competency skills, not just knowledge competencies, and 3) activity assessment instruments in accordance with one of the 2013 assessment curriculum strengthening, measuring student processes, not the results of their work.

\section{REFERENCES}

[1] Zulkifli, L., Gunawan, G., Jufri, A. W., Hadisaputra, S., \& Ramdani, A. (2019). Pengembangan Alat Evaluasi Pembelajaran Ipa Yang Mendukung Keterampilan Abad 21. Jurnal Penelitian Pendidikan IPA, 5(1). https://doi.org/10.29303/jppipa.v5i1.221

[2] Hilmi, N., Harjono, A., \& Soeprianto, H. (2018). Pengaruh Model Pembelajaran Discovery Dengan Pendekatan Saintifik Dan Keterampilan Proses Terhadap Hasil Belajar Fisika Peserta Didik. Jurnal Penelitian Pendidikan IPA, 3(2). https://doi.org/10.29303/jppipa.v3i2.85

[3] Aktamiş, H., \& Yenice, N. (2010). Determination of the science process skills and critical thinking skill levels. Procedia - Social and Behavioral Sciences, 2(2), 3282-3288. https://doi.org/10.1016/j.sbspro.2010.03.502

[4] Diartha, \& Muntari, W. 2. (2013). Jurnal Penelitian Pendidikan IPA (JPPIPA) PENGEMBANGAN PERANGKAT PENILAIAN KINERJA (PERFORMANCE ASSESSMENT) BERBASIS KURIKULUM 2013 PADA PEMBELAJARAN KIMIA KELAS XI.

[5] Li, H., Gobert, J., Graesser, A., \& Dickler, R. (2018). Advanced Educational Technology for Science Inquiry Assessment. Policy Insights from the Behavioral and Brain Sciences, 5(2), 171178. https://doi.org/10.1177/2372732218790017

[6] Sudria, I. B. N. M. S. (2009). Pengembangan Rubrik Penilaian Keterampilan Dasar Praktikum dan Mengajar Kimia pada Jurusan Pendidikan Kimia. Jurnal Pendidikan Dan Pengajaran, 42(3), 222-233.

[7] Wulan, A. R. (2009). Kemampuan Calon Guru Biologi Dalam Menyusun Rubrik Analitis Pada Asesmen Kinerja Pembelajaran B-288, 287-291.

[8] Ariyawati, P. A. M., Waluyo, J., \& Prihatin, J. (2017). Analisis Respon Siswa Terhadap Model Pairs, Investigation, and Communication (PIC) dalam Pembelajaran IPA. Jurnal Pembelajaran dan Pendidikan Sains, 2(1), 9-15.

[9] Sugiarti, S., Indrawati, \& Nuriman. (2017). Validitas Model Pembelajaran Batu Obsidianko (Baca, Tulis, Observasi, Diskusi, Analisis, Komunikasi) Untuk Pembelajaran IPA SMP. Jurnal Pembelajaran dan Pendidikan Sains, 2(1), 16-24.

[10] Kemdikbud. (2013). Pedoman Penilaian Hasil Belajar. Jakarta: Kemdikbud.

[11] Kunandar. (2014). Penilaian Autentik (Penilaian Hasil Belajar Peserta Didik Berdasarkan Kurikulum 2013). Jakarta: PT. Raja Grafindo Persada.

[12] Trianto. (2010). Model Pembelajaran Terpadu. Jakarta: Bumi Aksara. 